\title{
SURVIVAL OF GONOCOCCI IN URETHRAL SECRETIONS WITH REFERENCE TO THE NONSEXUAL TRANSMISSION OF GONOCOCCAL INFECTION
}

\author{
A. C. SRivastava* \\ Department of Venereology, Cardiff Royal Infirmary, Newport Road, Cardiff CF2 ISZ
}

GoNOCOCCl are assumed to be delicate organisms, but they can survive for at least $24 \mathrm{~h}$ in fluid pus at room temperature (Tulloch, 1929), and for 1-2 days in moist smears of pus (Stitt, Clough and Branham, 1948). Cruickshank (1960) and Cruickshank et al. (1975) reported that gonococci can survive for 3 days in pus on linen or other fabric. Elmros (1977) recovered gonococci from glass and towelling after $24 \mathrm{~h}$ and Elmros and Larsson (1972) found survival periods of $24 \mathrm{~h}$ on a towel and $17 \mathrm{~h}$ on glass. Berger and Döring (1969) reported survival on glass beads for 3-4 $\mathrm{h}$ and on cotton for 7-8 h. However, these researchers made only a few tests on two materials and satisfactory conclusion cannot be drawn from the results.

It has been recognised for many years that gonococci remain alive in moist pus but die rapidly when dried (Finger, Ghon and Schlagenhaufer, 1894; Neisser and Scholtz, 1903; Marshall, 1914). Jordan and Burrows (1942) and Bigger (1949) pointed out the significance of the inoculum size; gonococci have survived for several weeks dried in thick layers of pus (Bigger, 1949).

Nonvenereal gonococcal infection may be acquired from contaminated articles (Shore and Winkelstein, 1971; Doyle, 1972). In the past, epidemics of gonococcal vulvovaginitis in children were a serious problem in children's homes and hospitals (Jordan and Burrows, 1942). Thermometers, enema nozzles, examination gloves, nurses' aprons, towels, bed linen and chamber pots have also been implicated as vehicles for infection (Marshall, 1914; Keogh et al., 1916; Willcox, 1964; Grimble, 1969; Schofield, 1974; Catterall, 1975; King and Nicol, 1975).

The present study was undertaken to determine the survival periods of gonococci on a variety of materials that might be contaminated by an infected person. The medicolegal and social implications of the results were also considered.

\section{MATERIALS AND METHODS}

Test materials. Two groups of sterile test materials were contaminated with fresh gonococcal pus: (i) hard substances - glass microscope slide, plastic petri dish, Cellophane, wooden spatula, white cardboard, white paper; (ii) soft substances - plain cotton swab, charcoal-dipped cotton swab, cotton gauze, linen handkerchief, cotton towel, tissue paper, lubricated condom.

Gonococcal pus. Specimens of pus were obtained from male patients. The preliminary diagnosis of gonorrhoea was made on the basis of a gram-stained film of the pus, and primary cultures were made on Thayer-Martin medium (Thayer and Martin, 1966). These cultures were the positive controls; when the cultures were negative the experiments were void.

After "milking" of the patient's urethra, a globule of discharge was seeded directly on to one of the sterile materials. Only one object was contaminated with the secretion of each patient. The test materials were held in disposable foil trays away from radiators, direct sunshine and draughts for periods of $2-96 \mathrm{~h}$. The room temperature was $20-22^{\circ} \mathrm{C}$ and the relative humidity $c$. $60 \%$.

Recovery of gonococci. After the test period, the exudate deposited on the hard substances was scraped with a sterile, disposable scalpel on to plates of Thayer-Martin medium.

Received 7 Aug. 1979; revised version accepted 27 Feb. 1980.

\footnotetext{
* Present address: Department of Genitourinary Medicine, Royal Cornwall Hospital, Infirmary Hill, Truro, Cornwall.
} 
The exudate deposited on the soft materials was scraped on to one half of a culture plate with a disposable scalpel, and the material was rubbed gently on the other half of each plate. The residue of exudate on the material was washed with $0.5 \mathrm{ml}$ of sterile physiological saline so that the fluid fell on to a second plate and finally the material was placed on the plate. All plates were incubated at $37^{\circ} \mathrm{C}$ in air $+5 \% \mathrm{CO}_{2}$ for 4 days.

Identification of Neisseria gonorrhoeae. The recovery of N.gonorrhoeae on the Thayer-Martin cultures was confirmed by the growth of typical colonies that gave a positive oxidase reaction, a positive indirect fluorescent-antibody test and fermented glucose but not maltose or lactose.

\section{RESULTS}

The survival of gonococci on the test objects is shown in the table. Gonococci were recovered from most materials after $24-48 \mathrm{~h}$, and from a few materials after $72-96 \mathrm{~h}$. A large proportion of tests on all materials except the condom gave positive results when tested after 24 h. After $48 \mathrm{~h}$, gonococci were not recovered from tissue paper, linen, cotton towels or pieces of Cellophane, were recovered from $<50 \%$ of tests with cotton gauze, cotton swabs, glass slides, wooden spatulae, white cardboard and white paper, and were recovered from $50 \%$ of tests with charcoal-dipped cotton swabs and plastic petri dishes. After $72 \mathrm{~h}$, positive results were obtained only from a charcoal-dipped cotton swab, a piece of white cardboard and a wooden spatula, and after $96 \mathrm{~h}$ only one positive result was obtained from a piece of white cardboard.

Gonococci survived slightly longer in secretions deposited on hard materials than in secretions on soft materials, but this difference was not significant and the method used for the recovery of gonococci from the soft materials may have subjected the organisms to greater stress.

TABLE

Survival periods of gonococci in urethral secretions

\begin{tabular}{|c|c|c|c|c|c|c|c|c|c|c|c|c|c|c|}
\hline \multirow[t]{2}{*}{ Test material } & \multirow[t]{2}{*}{$\begin{array}{l}\text { Number } \\
\text { of tests }\end{array}$} & \multicolumn{13}{|c|}{$\begin{array}{l}\text { Results positive/total tests } \\
\text { after storage periods of }(h)\end{array}$} \\
\hline & & 2 & 4 & 6 & 8 & 10 & 12 & 20 & 24 & 30 & 36 & 48 & 74 & 96 \\
\hline White tissue paper & 19 & & & $\ldots$ & $\ldots$ & $\ldots$ & $1 / 1$ & $\ldots$ & $3 / 8$ & & & $0 / 4$ & $0 / 5$ & $0 / 1$ \\
\hline Lubricated condom & 49 & $0 / 3$ & $1 / 5$ & $1 / 2$ & $0 / 3$ & $1 / 3$ & $0 / 3$ & $\ldots$ & $0 / 11$ & $0 / 1$ & $0 / 1$ & $0 / 6$ & $0 / 8$ & $0 / 3$ \\
\hline Cotton gauze & 31 & $\ldots$ & $\ldots$ & $\ldots$ & $\ldots$ & $\ldots$ & $0 / 1$ & $0 / 1$ & $3 / 6$ & $1 / 1$ & $\ldots$ & $2 / 7$ & $0 / 9$ & $0 / 6$ \\
\hline White linen handkerchief & 54 & $1 / 1$ & $2 / 2$ & $1 / 1$ & $\ldots$ & $\ldots$ & $1 / 4$ & $2 / 4$ & $3 / 12$ & $\ldots$ & $0 / 3$ & $0 / 14$ & $0 / 8$ & $0 / 5$ \\
\hline White cotton towel & 40 & $\ldots$ & $1 / 1$ & $\ldots$ & $\ldots$ & $\ldots$ & $0 / 5$ & $2 / 4$ & $0 / 6$ & $\ldots$ & $0 / 1$ & $0 / 10$ & $0 / 10$ & $0 / 3$ \\
\hline Cotton swab & 36 & $\ldots$ & $\ldots$ & $\ldots$ & $\ldots$ & $\ldots$ & $1 / 1$ & $\ldots$ & $3 / 5$ & $\ldots$ & $0 / 3$ & $3 / 10$ & $0 / 9$ & $0 / 8$ \\
\hline Charcoal-dipped cotton swab & 40 & $\ldots$ & $\ldots$ & $\ldots$ & $\ldots$ & $\ldots$ & $0 / 1$ & $1 / 1$ & $3 / 3$ & $\ldots$ & $3 / 3$ & $4 / 8$ & $1 / 11$ & $0 / 13$ \\
\hline Glass slide & 35 & $\ldots$ & $\ldots$ & & $\ldots$ & $\ldots$ & $0 / 1$ & & $4 / 9$ & $1 / 1$ & $2 / 3$ & $2 / 8$ & $0 / 9$ & $0 / 4$ \\
\hline Wooden spatula & 43 & $\ldots$ & $\ldots$ & $\ldots$ & $\ldots$ & $\ldots$ & $\ldots$ & $\ldots$ & $5 / 10$ & $\ldots$ & $2 / 4$ & $1 / 10$ & $2 / 8$ & $0 / 11$ \\
\hline Cellophane & 28 & $\ldots$ & $\ldots$ & $\ldots$ & $\ldots$ & $\ldots$ & $2 / 4$ & & $5 / 10$ & $\ldots$ & $0 / 2$ & $0 / 5$ & $0 / 3$ & $0 / 4$ \\
\hline Plastic petri dish & 26 & $\ldots$ & $\ldots$ & $\ldots$ & $\ldots$ & $\ldots$ & $1 / 2$ & $0 / 1$ & $1 / 3$ & $\ldots$ & $0 / 1$ & $3 / 6$ & $0 / 6$ & $0 / 7$ \\
\hline White cardboard & 31 & $\ldots$ & $\ldots$ & $\ldots$ & $\ldots$ & $\ldots$ & $\ldots$ & $\ldots$ & $6 / 7$ & $\ldots$ & $0 / 3$ & $1 / 5$ & $1 / 6$ & $1 / 10$ \\
\hline White paper & 47 & $\ldots$ & $\ldots$ & $\ldots$ & $\ldots$ & $\ldots$ & $1 / 1$ & $\ldots$ & $3 / 13$ & $\ldots$ & $1 / 3$ & $2 / 8$ & $0 / 11$ & $0 / 11$ \\
\hline
\end{tabular}

\section{DISCUSSION}

The present studies confirm and extend the evidence that gonococci can survive for up to 3 days on some objects; some of the test strains of gonococci survived in exudates for longer periods on a wider variety of materials than has previously been shown. The longer the survival period, the greater is the chance of nonvenereal gonococcal infection from contact with a contaminated article.

The conflicting results of other studies may reflect the different experimental conditions of other groups of workers. Slow drying is less deleterious for gonococci than rapid drying (Tulloch, 1929; Morton, 1977) and although gonococci cannot be recovered from dried saline or broth suspension, survival is enhanced in purulent suspensions (Gilbaugh and Fuchs, 1979). 
However, the transmission of gonorrhoea does not depend solely upon a viable inoculum of gonococci. Kellogg et al. (1963) produced clinical gonorrhoea in volunteers with large doses of pure cultures of type- 1 gonococci, but similar doses of type- 4 strains were ineffective, and the inoculum size was unlikely in the natural transmission of the disease. Ward, Watt and Glynn (1970) found that gonococci from exudates were more resistant to the destructive action of antibody than strains from cultures and McEntegart (1975) concluded that there are other virulence and protective factors associated with the transmission of gonorrhoea that are absent from the organism in pure culture, so that infection by pure culture is never as consistently successful as infection by urethral pus from an infected patient.

In urethral exudate some gonococci within polymorphonuclear phagocytes are intact and occasionally appear to be dividing (Ward, Glynn and Watt, 1972; Farzadegan and Roth, 1975; Novotny, Short and Walker, 1975; Ovcvinnikov, Delektorskij and Dmitriev, 1976; Ovcvinnikov and Delektorskij, 1977; Veale et al., 1979); the capacity of gonococci to survive and grow within polymorphs may play a major role in their survival and infectivity and in the pathogenesis of gonorrhoea.

It is generally believed that nonsexual transmission of gonorrhoea is rare. Most doctors do not believe that adults can acquire genital gonorrhoea nonvenereally, although patients occasionally claim to have done so. The present evidence indicates that gonorrhoea might be acquired nonvenereally via fomites by adults, and physicians should consider this possibility because there may be serious social, emotional and medicolegal problems between patients, their consorts and their physicians.

\section{SUMMARY}

The survival of gonococci on various materials contaminated with gonococcal pus and stored at room temperature was studied. Gonococci were recovered for up to 3 days from a wide variety of hard and soft materials. It is possible that gonorrhoea is transmitted nonvenereally more often than is usually acknowledged, and these results may have medicolegal and social significance.

I am grateful to the staffs of the Departments of Venereology and Microbiology, Cardiff Royal Infirmary, for their help.

\section{REFERENCES}

Berger, U. AND DörIng, M. T. 1969. Zur Resistenz der humanen Neisseria-Arten gegen Austrocknung. Arch. Hyg. Bakt., 153, 556.

BigGeR, J. W. 1949. Handbook of bacteriology, 6th ed. Baillière, Tindall and Cox: London, p. 290.

Catterall, R. D. 1975. A short textbook of venereology, 2nd ed. English Universities Press: London, p. 22.

Cruickshank, R. (ed.) 1960. Mackie and McCartney's Handbook of bacteriology, 10th ed. Livingstone: Edinburgh, p. 508.

Cruickshank, R., Duguid, J. P., Marmion, B. P. and Swain, R. H. A. 1975. Neisseria. Medical microbiology, 12th ed. Churchill Livingstone: Edinburgh, vol. 2, p. 400.

DoyLE, J. O. 1972. Accidental gonococcal infection of the eyes in children. Br. med. J., 1, 88.

Elmros, T. 1977. Survival of Neisseria gonorrhoeae on surfaces. Acta Derm.-vener., Stockh., $57,177$.

ElmRos, T. ANd LaRsson, P.-A. 1972. Survival of gonococci outside the body. Br. med. J., 2, 403.

FarZADEGAN, H. AND Roth, I. L. 1975. Scanning electron microscopy and freeze etching of gonorrhoeal urethral exudate. Br. J. vener. Dis., 51, 83.

Finger, E., Ghon, A. And Schlagenhaufer, F. 1894. Beiträge zur Biologie des Gonococcus und zur pathologischen Anatomie des gonorrhoischen Processes. Arch. Derm. Syph., 28, 3. 
Gilbaugh, J. H. And Fuchs, P. C. 1979. The gonococcus and the toilet seat. N. Engl.J. Med., $301,91$.

Grimble, A. S. (ed.) 1969. McLachlan's Handbook of diagnosis and treatment of venereal diseases, 5th ed. Livingstone: Edinburgh, p. 128.

Jordan, E. O. AND Burrows, W. 1942. Textbook of bacteriology, 13th ed., revised. Saunders: Philadelphia, p. 320.

Kellogg, D. S., Peacock, W. L., Deacon, W. E., Brown, L. and Pirkle, C. I. 1963. Neisseria gonorrhoeae. 1. Virulence genetically linked to clonal variation. J. Bact., 85, 1274.

Keogh, A., Melville, C. H., Leishman, W., Pollock, C. E. and Harrison, L. W. 1916. A manual of venereal diseases, 2nd ed. Henry Frowde, Hodder \& Stoughton and Oxford University Press: London, p. 230.

KING, A. J. AND NICOL, C. 1975. Venereal diseases, 3rd ed. Baillière Tindall: London, p. 178.

MCEnTEgart, M. G. 1975. Fundamental research developments. In Recent advances in sexually transmitted diseases, edited by R. S. Morton and J. R. W. Harris, Churchill Livinstone: Edinburgh, no. 1, pp. 54-68.

Marshall, C. F. 1914. Syphilology and venereal diseases, 3rd ed. Baillière, Tindall and Cox: London, p. 380.

MoRTON, R. S. 1977. Gonorrhoea. Saunders: London, p. 31.

Neisser, A. AND Scholtz, W. 1903. Gonorrhoe. In Handbuch der Pathogenen Mikroorganismen, 1st ed., edited by W. Kolle and A. Wassermann. Gustav Fischer: Jena, vol. 3, p. 148.

Novotny, P., Short, J. A. AND Walker, P. D. 1975. An electron microscope study of naturally occurring and cultured cells of Neisseria gonorrhoeae. J. med. Microbiol., 8, 413.

Ovcrinnikov, N. M. AND DelektorskiJ, V. V. 1977. Phagocytosis in the urethral discharge from patients with gonorrhoea. In Gonorrhoea: epidemiology and pathogenesis, FEMS symposium no. 2, edited by F. A. Skinner, P. D. Walker and H. Smith. Academic Press: London, p. 157.

Ovcrinnikov, N. M., Delektorskij, V. V. And Dmitriev, G. A. 1976. Ultrastructure of gonococci in acute, chronic and asymptomatic gonorrhoea. Br. J. vener. Dis., 52, 230.

SCHOFIELD, C. B. S. 1974. Sexually transmitted diseases, 2nd ed. Churchill Livingstone: Edinburgh, p. 153.

SHORE, W. B. AND WinkelSTEIN, J. A. 1971. Nonvenereal transmission of gonococcal infection to children. J. Pediat., 79, 661 .

Stitt, E. R., Clough, P. W. and Branham, S. E. 1948. Practical bacteriology, hematology and parasitology, 10th ed. Lewis: London, p. 48.

ThAYER, J. D. AND MARTIN, J. E. 1966. Improved medium selective for cultivation of Neisseria gonorrhoeae and Neisseria meningitidis. Publ. Hlth Rep., 81, 559.

Tulloch, W. J. 1929. The gonococcus. In A system of bacteriology in relation to medicine, edited by the Bacteriological Committee of the Medical Research Council. HMSO: London, vol. 2, pp. 239-269.

Veale, D. R., Goldner, M., Penn, C. W., Ward, J. and Smith, H. 1979. The intracellular survival and growth of gonococci in human phagocytes. J. gen. Microbiol., 113, 383.

WARD, M. E., GlyNN, A. A. AND WATT, P. J. 1972. The fate of gonococci in polymorphonuclear leucocytes: an electronmicroscopic study of the natural disease. Br.J. exp. Path., 53, 289.

Ward, M. E., Watt, P. J. AND GlynN, A. A. 1970. Gonococci in urethral exudates possess a virulence factor lost on subculture. Nature, Lond., 227, 382.

Willcox, R. R. 1964. Textbook of venereal diseases and treponematoses, 2nd ed. William Heinemann Medical Books: London, p. 30. 